\title{
Antimicrobial active herbal compounds against Acinetobacter baumannii and other pathogens
}

\author{
Vishvanath Tiwari $^{\star}$, Ranita Roy ${ }^{\dagger}$ and Monalisa Tiwari ${ }^{\dagger}$ \\ Department of Biochemistry, Central University of Rajasthan, Ajmer, India
}

Bacterial pathogens cause a number of lethal diseases. Opportunistic bacterial pathogens grouped into ESKAPE pathogens that are linked to the high degree of morbidity, mortality and increased costs as described by Infectious Disease Society of America. Acinetobacter baumannii is one of the ESKAPE pathogens which cause

Edited by:

Márcia Vanusa Da Silva Universidade Federal de Pernambuco,

Brazi

Reviewed by:

Michael L. Vasil,

University of Colorado School of

Medicine, USA

Dinesh Sriramulu,

Shres Consultancy, India

Marco Rinaldo Oggioni,

University of Leicester, UK

*Correspondence:

Vishvanath Tiwari,

Department of Biochemistry,

Central University of Rajasthan

Ajmer-305817, India

vishvanath7@yahoo.co.in

${ }^{\dagger}$ These authors have contributed equally to this work.

Specialty section:

This article was submitted to

Antimicrobials, Resistance and

Chemotherapy

a section of the journal

Frontiers in Microbiology

Received: 12 March 2015

Accepted: 03 June 2015

Published: 18 June 2015

Citation:

Tiwari V, Roy R and TiwariM (2015)

Antimicrobial active herbal

compounds against Acinetobacter baumannii and other pathogens.

Front. Microbiol. 6:618.

doi: 10.3389/fmicb.2015.00618 respiratory infection, pneumonia and urinary tract infections. The prevalence of this pathogen increases gradually in the clinical setup where it can grow on artificial surfaces, utilize ethanol as a carbon source and resists desiccation. Carbapenems, a $\beta$-lactam, are the most commonly prescribed drugs against $A$. baumannii. The high level of acquired and intrinsic carbapenem resistance mechanisms acquired by these bacteria makes their eradication difficult. The pharmaceutical industry has no solution to this problem. Hence, it is an urgent requirement to find a suitable alternative to carbapenem, a commonly prescribed drug for Acinetobacter infection. In order to do this, here we have made an effort to review the active compounds of plants that have potent antibacterial activity against many bacteria including carbapenem resistant strain of $A$. baumannii. We have also briefly highlighted the separation and identification methods used for these active compounds. This review will help researchers involved in the screening of herbal active compounds that might act as a replacement for carbapenem.

Keywords: Acinetobacter baumannii, carbapenem resistance, antibacterial activity, herbal medicine, MIC

\section{Introduction}

Acinetobacter baumannii is a Gram-negative, non-motile, and non-fermentative coccus. It is known to cause nosocomial infections such as urinary tract infections, surgical site infection, meningitis, ventilator-associated pneumonia, bacteraemia, and very rarely intra-abdominal infections and infections of skin and central nervous system (Zarrilli et al., 2009). Clinical report showed that, the hospitalized patients who are infected with A. baumannii have about $30 \%$ chance of mortality (Perez et al., 2007). Acinetobacter are usually found in the hospital environment and infect patients who are hospitalized from a long period of time with severe underlying diseases, are immunosuppressed, or subjected to invasive procedures and treated with broad-spectrum antibiotics (Perez et al., 2007). These bacteria have been reported to colonize increasingly in the respiratory tract of patients admitted in Intensive Care Unit. In case of non-intensive care unit patients high rate of colonization of Acinetobacter strains are found on skin. During outbreaks along with one or more epidemic Acinetobacter clones, there exists an endemic strain which makes it difficult to identify and control their transmission (Marchaim et al., 2007; Oteo et al., 2007). 
A. baumannii have the ability to grow in diverse $\mathrm{pH}$ and temperature conditions and utilizes many different kinds of substrates for its growth (Tiwari and Tiwari, 2014). These are known to survive in both dry and moist condition and on inanimate objects like contaminated medical instruments including ventilators, catheters, respirometers (Cunha et al., 1980; Cefai et al., 1990; Horrevorts et al., 1995), pillows (Weernink et al., 1995), bed mattresses (Sherertz and Sullivan, 1985 ) etc. They are found widely in water and soil and some of them are also isolated from animals (Manchanda et al., 2010). Numerous cases of worldwide outbreaks due to A. baumannii depict increasing rates of resistance of these bacteria toward commercially available antibacterial agents.

Multi-drug resistant $A$. baumannii have been reported to be isolated from the hospitals in India (Tiwari et al., 2012; Tiwari and Moganty, 2013, 2014; Tiwari and Tiwari, 2015), Turkey (Vila et al., 2007), Taiwan (Lin et al., 2011), Argentina (Merkier and Centron, 2006), Korea (Chaulagain et al., 2012), Japan (Endo et al., 2012), Iran (Shahcheraghi et al., 2011), Saudi Arabia (Alsultan et al., 2009), Latin America, North America, Europe, Asia-Pacific rim (Mendes et al., 2010; Wang and Dowzicky, 2010), Brazil (Dalla-Costa et al., 2003; Gales et al., 2003; Sader et al., 2005; Tognim et al., 2006; Villegas et al., 2007), many countries of Asia and Middle-East (Afzal-Shah et al., 2001; Abbo et al., 2005; Jeon et al., 2005; Jeong et al., 2006; Chan et al., 2007; Ko et al., 2007; Koh et al., 2007), and also from Australia and Pacific islands (Anstey et al., 1992, 2002; Riley et al., 1996; Peleg et al., 2006; Iredell et al., 2007; Playford et al., 2007; Valenzuela et al., 2007). Previous reports suggested that some MDR strains of A. baumannii spread from regions of Spain (Culebras et al., 2010), with high antibacterial resistance rates, to regions like Norway, experiencing low rates of resistance. It was also reported that the US military personnel and civilians have received medical support in United Kingdom when they were infected by the MDR strains, while posted in an operation in Iraq and Afghanistan (Perez et al., 2007). Gradually since the late 1970s, cases of resistance started developing against most classes of drugs. In the late 1990s, the only effective therapeutic option left was carbapenem. In recent years, A. baumannii was also found to become resistant to carbapenem making its treatment more and more difficult. Various resistance mechanisms have been acquired by A. baumannii against carbapenem (Manchanda et al., 2010), such as presence of antimicrobial-inactivating enzymes, i.e., $\beta$-lactamase (Brown et al., 2005; Chuang et al., 2010; Rodriguez-Martinez et al., 2010; Acosta et al., 2011; Santella et al., 2011), decreased access to bacterial targets (because of reduced permeability of the outer membrane caused by loss of or low porin expression, increased expression of multidrug efflux pumps) (Fernandez-Cuenca et al., 2003; Wilke et al., 2005; Hu et al., 2007; Vila et al., 2007; Vashist et al., 2010), and mutations altering targets or different cellular functions. These mechanisms may act in combination also for a single strain (FernandezCuenca et al., 2003; Rice, 2006).

Although no antibiotics with specific cellular targets have been isolated from plants but modified plant natural antibiotics has been more successful such as penicillin (Lewis and Ausubel, 2006). Attempts to develop potent antibiotics from plants have failed by both pharmaceutical and biotech firms. A reason for this may be the use of varying chemical strategy by the plants to control bacterial infection, in order to reduce the selective pressure for developing resistance to antibiotics. For instance, antibacterial active compounds may act quite effectively in combinations and have little potency alone. Plant alkaloid berberine has excellent antibacterial properties but it is ineffective when acting alone as it is a preferred substrate of bacterial encoded MDRs (multidrug resistance pumps). 5' methoxyhydnocarpin, a compound isolated from the same plant as berberine blocks the MDRs and therefore enabling berberine to act as a potent antibacterial agent in presence of this compound. So it is very necessary to first identify the antibacterial mechanism of the plants and then screen pharmaceutically to develop some effective antibiotic (Lewis and Ausubel, 2006).

Since there is no new development of antibiotics against the carbapenem resistant strains of $A$. baumannii therefore, it is necessary to focus on the antimicrobial activity of plant derived substances that are being used in traditional medicine worldwide (Savoia, 2012). Secondary metabolites are responsible for the antimicrobial activity of plants. In this present review, we have explained the various herbal active compounds which have potent activity against A. baumannii and other Gramnegative bacteria. This will initiate the search for new antibiotics from herbal origin against the resistant strains of Acinetobacter baumannii and this may lead to the development of new antibiotics.

\section{Extraction of Plant Active Compounds and its Identification}

Numerous works have been done to isolate and characterize bioactive compounds from plant resources that are active against Gram-positive and Gram-negative bacteria, fungi and viruses. Miyasaki reported that generally flavones, tannins and phenolic compounds are known to be active against Acinetobacter (Miyasaki et al., 2013). Many active herbal compounds have been isolated and reported for their activities. These secondary metabolites were extracted using different solvents such as methanol, ethanol, water, hydroxide, acetone, and through various techniques like HPLC, column chromatography from plant materials. After extraction of the plant materials, elucidation of the active metabolites and their structures were performed by different methods. The methods include GC-MS (gas chromatography-mass spectrometer), LC-MS (liquid chromatography-mass spectrometer), and NMR (nuclear magnetic resonance).

The efficiency for separating and identifying compounds from complex biological mixture is very high for GC-MS (VillasBoas et al., 2005). It is capable of simultaneously identifying and profiling several compounds that possess different functions. This is mostly used for making the fingerprints of compounds that are volatile in nature which somewhat make the analyzing process repetitive and time consuming (Formisano et al., 2012; Huang et al., 2012; Wang et al., 2012). GC-MS can be used for compounds having lower molecular mass and that are volatile 
or semi volatile in nature (Villas-Boas et al., 2005; Dunn et al., 2011). Here, the capillary column has a low flow rate, so that output of the column can be directly put to MS ionization chamber (Oleszek and Marston, 2000; Phillipson, 2007; Daffre et al., 2008). Besides GC-MS, another most important analytical technique is LC-MS where liquid chromatography is coupled to mass spectrometry along with electrospray ionization and atmospheric pressure chemical ionization (Villas-Boas et al., 2005). It can identify and analyze a large number of compounds, present in small quantities whose molecular mass vary from 10 to 300,000 with varying chemical properties (Hagel and Facchini, 2008). As compared to GC-MS, sample preparation is quite simple in case of LC/MS (Dunn and Ellis, 2005). By LC/MS analysis, high resolution mass accuracy can be achieved which is important for analyzing herbal active compounds. This property is enhanced by the use of ultra-performance liquid chromatography. It can also be said that LC-MS is more preferred over GC-MS in reducing time and money for sample preparation. NMR spectra provide great information about the structures of the compounds along with their identification via interpretation of spectra involving chemical shift and chemical constants. It is quantitative, reproducible, non-sample destructive, and nonspecific which makes it superior to other analytical techniques (Dunn et al., 2011).

The antibacterial components of various plants, their separation and identification techniques are listed below in Table 1. Some of these herbal compounds have the ability to work alone or in presence of the other, i.e., in synergy which are also explained in Table 1.

\section{Plant Active Compounds against Gram-Negative Bacteria}

The antibacterial components of various plants were screened against a wide range of Gram-positive as well as Gram-negative bacteria mostly by MIC, disk diffusion assay and CFU. It was found that some of the compounds were more active against Gram-positive whereas some were more active against Gram-negative bacteria. The Gram-positive bacteria that are tested against different active compounds of plants include Staphylococcus aureus, Bacillus cereus, Helicobacter pylori, Salmonella enteritidis, and Clostridium jejuni (see Table 2). The Gram-negative bacteria like Klebsiella pneumoniae, Enterobacter aerogenes, Providencia stuartii, Escherichia coli, Enterobacter cloacae, and Pseudomonas aeruginosa are susceptible toward the active compounds of Hibiscus subdarifa, L. salicaria, Adansonia digitata, Commiphora molmol, etc. (see Table 2).

\section{Plant Active Compounds against Acinetobacter baumannii}

This study is aimed to review the literature regarding herbal active compounds against various bacteria, including Acinetobacter baumannii. Hence, we have listed most of the plants in Table 2, which are reported to inhibit this pathogen by varying mechanisms. L. salicaria shows significant activity against different bacteria but, especially A. baumannii and $P$. aeruginosa. Hence its topical form may be used to treat infections of skin and soft tissue (antiseptic), infections of burn wounds, diabetic foot and decubitus wound caused by these MDR bacterial strains. It is already known that this plant has been used as traditional medicine for many indications, but to use it clinically, several in vitro and in vivo test have to be performed(Guclu et al., 2014).

Saulnier et al. used essential oils of herbs like Syzygium aromaticum, Cinnamomum zeylanicum, and Thymus in nano medicine against multidrug-resistant $A$. baumannii. Cinnamaldehyde prevents the activity of amino acid decarboxylase in the bacteria (Burt, 2004), but it is unable to disorganize outer membrane of cell or deplete intracellular ATP concentration. Hydroxyl group of carvacrol and eugenol (phenolic compounds) can disrupt the bacterial cell wall. This phenomenon has the potential to decrease intracellular ATP pool and membrane potential (Ultee et al., 2002; Gill and Holley, 2006). It also results in the leakage of various substances such as ATP, amino acids, ions, and nucleic acids ultimately leading to bacterial death. MIC of active components is the same as MIC of those compounds when nano-encapsulated. Lipidic nanocapsules (LNC) can be made more effective by improving their presence in systemic circulation through the modifications on LNC surface. It can be a good alternative of antibiotics (Saulnier, 2014).

Curcumin alone had very little antibacterial activity against $A$. baumannii strains with high MIC $(256 \mu \mathrm{g} / \mathrm{ml})$. The antibacterial activity of curcumin is due to several reasons for instance, disruption of folic acid metabolism (shikimate dehydrogenase) pathway (De et al., 2009) and bacterial cell division (Rai et al., 2008). Combinatorial use of curcumin and epigallocatechin gallate (EGCG) is very much effective in increasing the inhibition level by many folds, making the MIC $4 \mu \mathrm{g} / \mathrm{ml}$. This study indicates synergistic effects to prevent $A$. baumannii growth between curcumin and EGCG without any antagonistic effects (Betts and Wareham, 2014). In the same way epicatechin, a tea polyphenol having no antibacterial properties can potentiate theaflavin, increasing its activity against A. baumannii and S. maltophilia isolates. The probable mechanism may be that epicatechin inhibits theaflavin oxidation thus enhancing its antibacterial effect, but the exact mechanism of synergy is not yet understood and needs further study (Betts et al., 2011).

Khadri, et al. reported the presence of methyl allyl trisulfide (34.61\%) and diallyl disulfide (31.65\%) with other compounds at relatively lower levels after GC/MS analysis in Allium sativium. It showed significant activity against $P$. aeruginosa in vitro and can be used for treating infections caused by this pathogen (Khadri et al., 2010). Aloe vera gel extract were reported to be more active for Gram-positive than Gram-negative bacteria. Ethanol extract was most active followed by methanol extract activity and least inhibition was exhibited by acetone extract (Lawrence et al., 2009). Magnolia dealbata extracts showed good inhibition zone of $>10 \mathrm{~mm}$ against $P$. aeruginosa, Clavibacter michiganensis, A. baumannii, A. iwoffii. Generally, the active constituents of $M$. dealbata like honokiol and magnolol possess selective antimicrobial activities against drug resistant Gram-negative 
TABLE 1 | Antibacterial components of plants with their extraction and identification methods.

\begin{tabular}{|c|c|c|c|c|c|}
\hline Plant (Common name) & Antibacterial compounds & Extracted from & Separation methods & $\begin{array}{l}\text { Identification } \\
\text { methods }\end{array}$ & References \\
\hline $\begin{array}{l}\text { Rosa rugosa (Japanese } \\
\text { rose) }\end{array}$ & Ellagic acid & $\begin{array}{l}\text { Dry powders of plant } \\
\text { extract }\end{array}$ & HPLC & LC/MS, NMR & $\begin{array}{l}\text { Miyasaki et al., } \\
2013\end{array}$ \\
\hline $\begin{array}{l}\text { Terminalia chebula } \\
\text { (Myrobalan/Hardad) }\end{array}$ & $\begin{array}{l}\text { Chebulagic acid, Chebulinic } \\
\text { acid, Corilagin, and } \\
\text { Terchebulin }\end{array}$ & $\begin{array}{l}\text { Dry powders of plant } \\
\text { extract }\end{array}$ & HPLC & LC/MS, NMR & $\begin{array}{l}\text { Miyasaki et al., } \\
2013\end{array}$ \\
\hline $\begin{array}{l}\text { Scutellaria baicalensis } \\
\text { (Baical skullcap) }\end{array}$ & $\begin{array}{l}\text { Norwogonin, Baicalin, and } \\
\text { Baicalein }\end{array}$ & $\begin{array}{l}\text { Dry powders of plant } \\
\text { extract }\end{array}$ & $\begin{array}{l}\text { HPLC, Aqueous and } \\
\text { ethanolic extract }\end{array}$ & LC/MS, NMR & $\begin{array}{l}\text { Chan et al., 2011; } \\
\text { Miyasaki et al., } \\
2013\end{array}$ \\
\hline $\begin{array}{l}\text { Lythrum salicaria (Purple } \\
\text { loosestrife) }\end{array}$ & $\begin{array}{l}\text { Hexahydroxy diphenoyl } \\
\text { ester vescalagin }\end{array}$ & Flowers and leaves & $\begin{array}{l}\text { Methanolic extract, } \\
\text { Column } \\
\text { chromatography }\end{array}$ & N/A & $\begin{array}{l}\text { Becker et al., } \\
\text { 2005; Guclu et al. } \\
2014\end{array}$ \\
\hline $\begin{array}{l}\text { Cinnamomum } \\
\text { zeylanicum }^{\mathrm{a}, \mathrm{b}} \\
\text { (Cinnamon/Dalchini) }^{\text {(C) }}\end{array}$ & Trans-cinnamaldehyde & Essential leaf oil & N/A & N/A & $\begin{array}{l}\text { Pelletier, 2012; } \\
\text { Saulnier, } 2014\end{array}$ \\
\hline $\begin{array}{l}\text { Oreganum vulgare }{ }^{\mathrm{a}, \mathrm{b}} \\
\text { (Oregano) }\end{array}$ & Carvacrol & Essential leaf oil & N/A & N/A & $\begin{array}{l}\text { Pelletier, 2012; } \\
\text { Saulnier, } 2014\end{array}$ \\
\hline $\begin{array}{l}\text { Thymus }^{\mathrm{b}} \text { (Common } \\
\text { thyme/Garden thyme) }\end{array}$ & Thymol & Essential leaf oil & N/A & N/A & Pelletier, 2012 \\
\hline $\begin{array}{l}\text { Curcuma longac } \\
\text { (Turmeric/Haldi) }\end{array}$ & Curcumin & Plant extract powder & Methanolic extract & N/A & $\begin{array}{l}\text { Betts and } \\
\text { Wareham, } 2014\end{array}$ \\
\hline $\begin{array}{l}\text { Lycium chinense Mill. } \\
\text { (Cortex lycii/Wolfberry) }\end{array}$ & $\begin{array}{l}\text { (+)-Lyoniresinol-3 alpha-O- } \\
\text { beta-D-glucopyranoside }\end{array}$ & Herbal materials & $\begin{array}{l}\text { Aqueous and ethanolic } \\
\text { extract }\end{array}$ & N/A & Chan et al., 2011 \\
\hline $\begin{array}{l}\text { Paeonia suffruticosa Andr. } \\
\text { (Cortex moutan) }\end{array}$ & Paeonol & Herbal materials & $\begin{array}{l}\text { Aqueous and ethanolic } \\
\text { extract }\end{array}$ & N/A & Chan et al., 2011 \\
\hline $\begin{array}{l}\text { Coptidis chinensis Franch. } \\
\text { (Rhizoma coptidis) }\end{array}$ & Berberine & Herbal materials & $\begin{array}{l}\text { Aqueous and ethanolic } \\
\text { extract }\end{array}$ & N/A & Chan et al., 2011 \\
\hline $\begin{array}{l}\text { Berberis fremontii (Desert } \\
\text { barberry) }\end{array}$ & Berberine & Leaves & Hexane extract & NMR, MS & $\begin{array}{l}\text { Stermitz et al., } \\
\text { 2000; Lewis and } \\
\text { Ausubel, } 2006\end{array}$ \\
\hline $\begin{array}{l}\text { Hydrastis Canadensis } \\
\text { (Goldenseal) }\end{array}$ & Berberine & Aerial parts & $\begin{array}{l}\text { Aqueous and ethanolic } \\
\text { extract }\end{array}$ & LC-MS & $\begin{array}{l}\text { Lewis and } \\
\text { Ausubel, 2006; } \\
\text { Ettefagh et al., } \\
2011\end{array}$ \\
\hline Azadirachta indica (Neem) & $\begin{array}{l}\text { stigmasterol, nimbiol, sugiol, } \\
\text { 4-cymene, } \alpha \text {-terpinene, } \\
\text { terpinen-4-ol }\end{array}$ & Leaves, bark & Methanolic extract & GC-MS & Nand et al., 2012 \\
\hline
\end{tabular}


TABLE 1 | Continued

\begin{tabular}{|c|c|c|c|c|c|}
\hline Plant (Common name) & Antibacterial compounds & Extracted from & Separation methods & $\begin{array}{l}\text { Identification } \\
\text { methods }\end{array}$ & References \\
\hline $\begin{array}{l}\text { Aloe vera (Indian aloe, Ghi } \\
\text { Kunvar) }\end{array}$ & $\begin{array}{l}\text { p-coumaric acid, ascorbic } \\
\text { acid, pyrocatechol cinnamic } \\
\text { acid }\end{array}$ & Leaves & $\begin{array}{l}\text { ethanol, methanol and } \\
\text { acetone extracts, thin } \\
\text { layer and column } \\
\text { chromatography }\end{array}$ & GC-MS & $\begin{array}{l}\text { Lawrence et al., } \\
2009\end{array}$ \\
\hline Allium sativum (Garlic) & $\begin{array}{l}\text { allyl methyl disulfide, } \\
\text { diallylsulfide, diallyltrisulfide, } \\
\text { allyl methyl trisulfide, diallyl } \\
\text { disulfide }\end{array}$ & Bulbs & HPLC & GC-MS & $\begin{array}{l}\text { Khadri et al., 2010; } \\
\text { Lu et al., } 2011\end{array}$ \\
\hline $\begin{array}{l}\text { Magnolia dealbata } \\
\text { (Cloudforest magnolia) }\end{array}$ & Honokiol, magnolol & Seeds & Ethanolic extract & $\mathrm{N} / \mathrm{A}$ & $\begin{array}{l}\text { Jacobo-Salcedo } \\
\text { Mdel et al., } 2011\end{array}$ \\
\hline $\begin{array}{l}\text { Rabdosia rubescens } \\
\text { (Blushred rabdosia) }\end{array}$ & $\begin{array}{l}\text { phaeophytin a, phaeophytin } \\
\text { b, } \\
\text { 17c-ethoxypheaophorbide } \\
\text { a, 17c-ethoxyphea } \\
\text { ophorbide b, oleanolic acid, } \\
\text { physcion, emodin-8-O- } \\
\text { beta-D-glucopyranoside, } \\
\text { isorhamnetin }\end{array}$ & $\mathrm{N} / \mathrm{A}$ & $\begin{array}{l}\text { ODS column } \\
\text { chromatography }\end{array}$ & NMR and MS & Lv and Xu, 2008 \\
\hline
\end{tabular}

a Syzygium aromaticum, Cinnamomum zeylanicum, Oreganum vulgare shows synergism.

${ }^{b}$ Syzygium aromaticum, Cinnamomum zeylanicum, Oreganum vulgare and Thymus shows synergism.

${ }^{c}$ Curcuma longa and Camellia sinensis (Green tea) exhibits synergism.

${ }^{d}$ Camellia sinensis (Green tea) and Camellia sinensis (Black tea) exhibits synergism.

bacterial species and fungal pathogens (Jacobo-Salcedo Mdel et al., 2011).

Miyasaki et al. (2013) suggested in their studies, norwogonin (5,6,7-trihydroxyflavone) extracted from Scutellaria baicalensis, has an $\mathrm{MIC}_{90}$ of $128 \mu \mathrm{g} / \mathrm{ml}$ against some strains of $A$. baumannii. Chebulagic acid, chebulinic acid (65\% inhibition at $62.5 \mu \mathrm{g} / \mathrm{ml}$ ), ellagic acid (67\% inhibition at $250 \mu \mathrm{g} / \mathrm{ml})$, corilagin, and terchebulin extracted from Terminalia chebula had lower activity against $A$. baumannii in vitro. Other constituents of Scutellaria baicalensis, baicalin and baicalein are also found to be active against other bacteria. Corilagin, chebulagic acid, and terchebulin of Terminalia chebula exhibits a two-step killing kinetic. The medical literature reported that many phenolic compounds of plant extracts enhance the potential of synthetic antibiotics against $A$. baumannii in vitro (Miyasaki et al., 2013). For instance, activity of rifampicin, coumermycin, fusidic acid, novobiocin, and chlorobiocin was enhanced by tannic acid and ellagic acid against A. baumannii in vitro (Chusri et al., 2009). Even synergy was observed between topical mafenide and green tea polyphenol against multi-drug resistance Acinetobacter baumannii in-vitro (Osterburg et al., 2009), while no effect of synergy was noted between any antibiotics for Gram-negative bacteria and norwogonin.

Some Chinese medicines extracted from different plants have been reported to exhibit significant antibacterial activities. The active constituent of Rhizoma coptidis is berberine, an alkaloid possessing various antimicrobial activities. Berberine is also isolated from Berberis fremontii and Hydrastis canadensis (Lewis and Ausubel, 2006) It has anti-Herpes simplex virus effects and at moderate concentrations $(30-45 \mu \mathrm{g} / \mathrm{ml})$ sufficient antibacterial effect was observed along with inhibition of biofilm formation. Plant derived antibacterial molecule are generally weak but work better in synergy with antibiotics (Lewis and Ausubel, 2006). Synergism was also seen for berberine and $\beta$ lactam antibiotics against multi drug resistant $S$. aureus. (+)Lyoniresinol-3 alpha-O-beta-D-glucopyranoside of Cortex Lycii presented strong antimicrobial effect against multi drug resistant S. aureus isolated from patients and some pathogenic fungi, but it did not cause any haemolysis on human RBCs. This also possesses potent antifungal activities against Candida albicans. There is very limited literature concerned with the antibacterial effects of Cortex Moutan. The ethanolic extract of Cortex Moutan suppress the growth of S. aureus (Chan et al., 2011). Only paeonol is identified as active ingredients till date, which is responsible for its anti-microbial effects on C. albicans, C. tropicalis, and C. glabrata etc. (Chan et al., 2011).

A very common medicinal plant $A$. indica is the source of various active compounds identified by GC/MS analysis possessing versatile effects like anti-bacterial, anti-inflammatory, antioxidant activities (Nand et al., 2012). Hence further studies can be performed to see its activity against Gram-negative bacteria and especially A. baumannii.

\section{Conclusion and Future Prospects}

Emergence of resistant strains of bacterial pathogens is a major source of high morbidity, mortality, and increased cost, making its treatment much more difficult. Traditionally, plants play 
TABLE 2 | List of bacteria susceptible to the bioactive herbal components.

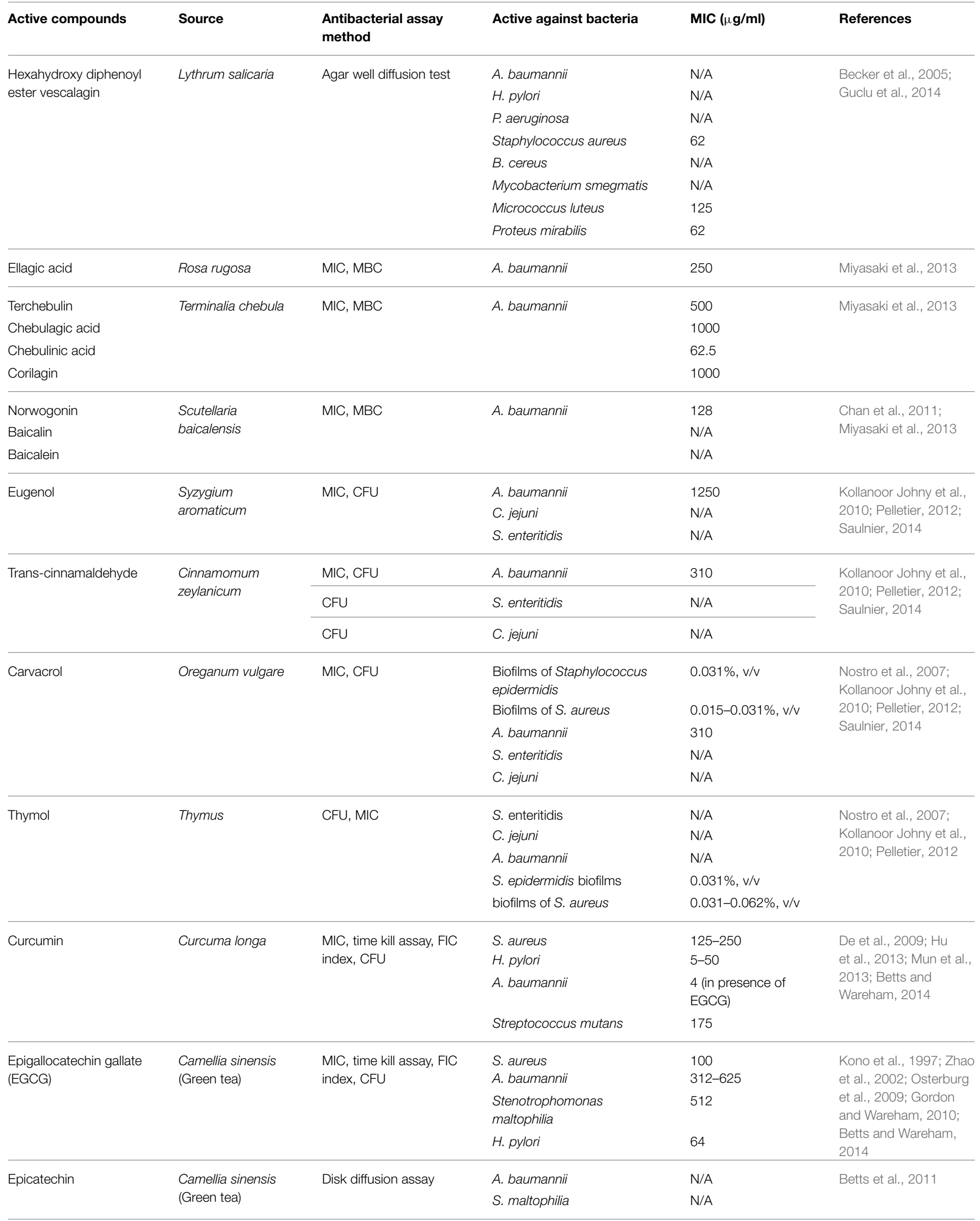




\section{TABLE 2 | Continued}

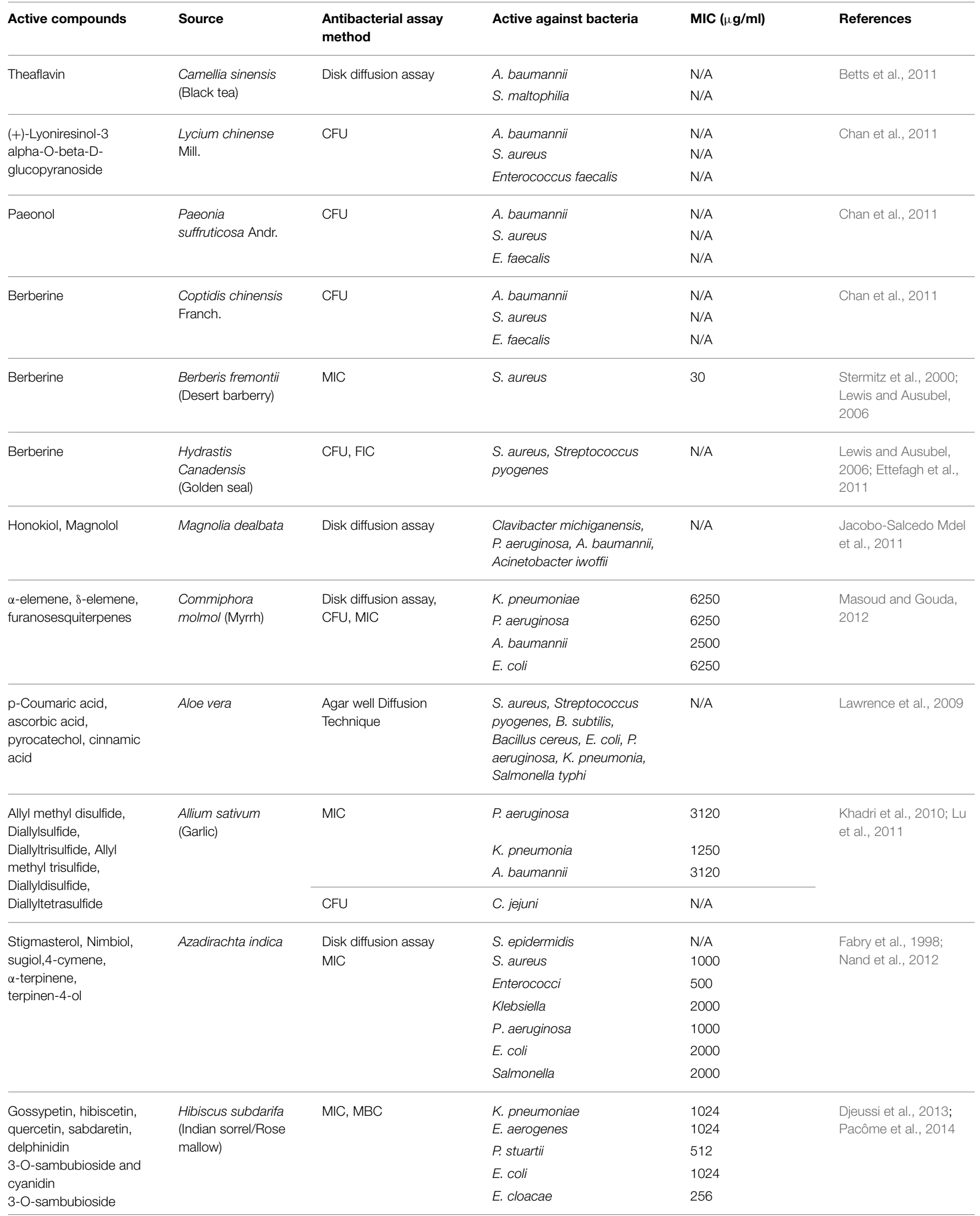


TABLE 2 | Continued

\begin{tabular}{|c|c|c|c|c|c|}
\hline Active compounds & Source & $\begin{array}{l}\text { Antibacterial assay } \\
\text { method }\end{array}$ & Active against bacteria & $\operatorname{MIC}(\mu \mathrm{g} / \mathrm{ml})$ & References \\
\hline \multirow{3}{*}{$\begin{array}{l}\text { Quercetin-7-0-B-D- } \\
\text { xylopyranoside, } \\
\text { 7-baueren-3-acetate }\end{array}$} & \multirow{3}{*}{$\begin{array}{l}\text { Adansonia digitata } \\
\text { (Baobab/Gorakh } \\
\text { imli) }\end{array}$} & \multirow[t]{3}{*}{$\mathrm{MIC}, \mathrm{MBC}$} & K. pneumoniae & 1024 & \multirow[t]{3}{*}{ Djeussi et al., 2013} \\
\hline & & & E. cloacae & 1024 & \\
\hline & & & Providencia stuartii & 1024 & \\
\hline
\end{tabular}

MIC, Minimum Inhibitory Concentration; MBC, Minimum Bactericidal Concentration; FIC, Fractional Inhibitory Concentration; CFU, Colony Forming Units.

an important role in treatment of diseases, hence it may be used as a source to find out alternative drug to carbapenem. Plants possess secondary metabolites that are reported to be potentially active against a wide variety of bacteria. It was also found that the herbal compounds are weak antibacterials but showed better antimicrobial activity when used in synergy with other antibiotics. The advancement in the techniques for separation, purification and identification of bioactive compounds make it possible to chemically and structurally identify these compounds. In present review, we have made an effort to list a number of plant active compounds that may have potent antibacterial activity against some Gram-positive and Gram-negative bacteria including carbapenem resistant strain of A. baumannii. Hence, the use of different plant natural compounds as antibacterial agents is an interesting strategy for discovering bioactive products that could become useful therapeutic tools. This review will help researchers involved in the screening of herbal active compounds that might act as a replacement for carbapenem, a $\beta$-lactam. In this review we found a compound named norwogonin which has good antibacterial

\section{References}

Abbo, A., Navon-Venezia, S., Hammer-Muntz, O., Krichali, T., Siegman-Igra, Y., and Carmeli, Y. (2005). Multidrug-resistant Acinetobacter baumannii. Emerg. Infect. Dis. 11, 22-29. doi: 10.3201/eid1101.040001

Acosta, J., Merino, M., Viedma, E., Poza, M., Sanz, F., Otero, J. R., et al. (2011). Multidrug-resistant Acinetobacter baumannii Harboring OXA24 carbapenemase, Spain. Emerg. Infect. Dis. 17, 1064-1067. doi: 10.3201/eid/1706.091866

Afzal-Shah, M., Woodford, N., and Livermore, D. M. (2001). Characterization of OXA-25, OXA-26, and OXA-27, molecular class D beta-lactamases associated with carbapenem resistance in clinical isolates of Acinetobacter baumannii. Antimicrob. Agents Chemother. 45, 583-588. doi: 10.1128/AAC.45.2.583588.2001

Alsultan, A. A., Hamouda, A., Evans, B. A., and Amyes, S. G. (2009). Acinetobacter baumannii: emergence of four strains with novel bla(OXA-51like) genes in patients with diabetes mellitus. J. Chemother. 21, 290-295. doi: 10.1179/joc.2009.21.3.290

Anstey, N. M., Currie, B. J., Hassell, M., Palmer, D., Dwyer, B., and Seifert, H. (2002). Community-acquired bacteremic Acinetobacter pneumonia in tropical Australia is caused by diverse strains of Acinetobacter baumannii, with carriage in the throat in at-risk groups. J. Clin. Microbiol. 40, 685-686. doi: 10.1128/JCM.40.2.685-686.2002

Anstey, N. M., Currie, B. J., and Withnall, K. M. (1992). Community-acquired Acinetobacter pneumonia in the Northern Territory of Australia. Clin. Infect. Dis. 14, 83-91. doi: 10.1093/clinids/14.1.83 activity $\left(\mathrm{MIC}_{90}-128 \mu \mathrm{g} / \mathrm{ml}\right)$ against A. baumannii. Hence, special emphasis can be given on this compound in further studies in order to use it as an alternative of carbapenem. Effect of this compound on other bacteria can also be screened. There are some plants shown in Table 2 that shows good activity against many bacteria like Allium sativum, Adansonia digitata, Hibiscus subdarifa, etc., have not been tested against $A$. baumannii. Therefore, activities of these plants can also be tested against $A$. baumannii. Screened herbal active compound may be tested in the future for its antimicrobial activity. In-silico approach can also be used to modify the structure of active compound for its better antibacterial activity against carbapenem resistant strain of $A$. baumannii. Potential plant active compound may be chemically synthesized and used as an alternative to carbapenem.

\section{Acknowledgments}

VT would like to thanks UGC, India (UGC/BSR/F.No.3018/2014) for Start Up grant and SERB, DST, India for Start Up grant (SB/YS/LS-07/2014).
Becker, H., Scher, J. M., Speakman, J. B., and Zapp, J. (2005). Bioactivity guided isolation of antimicrobial compounds from Lythrum salicaria. Fitoterapia 76, 580-584. doi: 10.1016/j.fitote.2005.04.011

Betts, J. W., Kelly, S. M., and Haswell, S. J. (2011). Antibacterial effects of theaflavin and synergy with epicatechin against clinical isolates of Acinetobacter baumannii and Stenotrophomonas maltophilia. Int. J. Antimicrob. Agents 38, 421-425. doi: 10.1016/j.ijantimicag.2011. 07.006

Betts, J. W., and Wareham, D. W. (2014). In vitro activity of curcumin in combination with epigallocatechin gallate (EGCG) versus multidrug-resistant Acinetobacter baumannii. BMC Microbiol. 14:172. doi: 10.1186/1471-218014-172

Brown, S., Young, H. K., and Amyes, S. G. (2005). Characterisation of OXA-51, a novel class D carbapenemase found in genetically unrelated clinical strains of Acinetobacter baumannii from Argentina. Clin. Microbiol. Infect. 11, 15-23. doi: 10.1111/j.1469-0691.2004.01016.x

Burt, S. (2004). Essential oils: their antibacterial properties and potential applications in foods-a review. Int. J. Food Microbiol. 94, 223-253. doi: 10.1016/j.ijfoodmicro.2004.03.022

Cefai, C., Richards, J., Gould, F. K., and Mcpeake, P. (1990). An outbreak of Acinetobacter respiratory tract infection resulting from incomplete disinfection of ventilatory equipment. J. Hosp. Infect. 15, 177-182. doi: 10.1016/01956701(90)90128-B

Chan, B. C.-L., Lau, C. B.-S., Jolivalt, C., Lui, S.-L., Ganem-Elbaz, C., Paris, J.-M., et al. (2011). "Chinese medicinal herbs against antibiotic-resistant bacterial pathogens," in Science Against Microbial Pathogens: Communicating 
Current Research and Technological Advances, Vol. 2, ed A. Méndez-Vilas (Extremadura: Formatex). 773-781.

Chan, P. C., Huang, L. M., Lin, H. C., Chang, L. Y., Chen, M. L., Lu, C. Y., et al. (2007). Control of an outbreak of pandrug-resistant Acinetobacter baumannii colonization and infection in a neonatal intensive care unit. Infect. Control Hosp. Epidemiol. 28, 423-429. doi: 10.1086/513120

Chaulagain, B. P., Jang, S. J., Ahn, G. Y., Ryu, S. Y., Kim, D. M., Park, G., et al. (2012). Molecular epidemiology of an outbreak of imipenem-resistant Acinetobacter baumannii carrying the ISAba1-bla(OXA-51-like) genes in a Korean hospital. Jpn. J. Infect. Dis. 65, 162-166.

Chuang, Y. C., Chang, S. C., and Wang, W. K. (2010). High and increasing Oxa-51 DNA load predict mortality in Acinetobacter baumannii bacteremia: implication for pathogenesis and evaluation of therapy. PLoS ONE 5:e14133. doi: 10.1371 /journal.pone. 0014133

Chusri, S., Villanueva, I., Voravuthikunchai, S. P., and Davies, J. (2009). Enhancing antibiotic activity: a strategy to control Acinetobacter infections. J. Antimicrob. Chemother. 64, 1203-1211. doi: 10.1093/jac/dkp381

Culebras, E., Gonzalez-Romo, F., Head, J., Gomez, M., Morales, G., and Picazo, J. J. (2010). Outbreak of Acinetobacter baumannii producing OXA-66 in a Spanish hospital: epidemiology and study of patient movements. Microb. Drug Resist. 16, 309-315. doi: 10.1089/mdr.2009.0113

Cunha, B. A., Klimek, J. J., Gracewski, J., Mclaughlin, J. C., and Quintiliani, R. (1980). A common source outbreak of Acinetobacter pulmonary infections traced to Wright respirometers. Postgrad. Med. J. 56, 169-172. doi: 10.1136/pgmj.56.653.169

Daffre, S., Bulet, P., Spisni, A., Ehret-Sabatier, L., Rodrigues, E., and Travassos, L. R. (2008). Bioactive natural peptides. Stud. Nat. Prod. Chem. 35, 597-691. doi: 10.1016/S1572-5995(08)80015-4

Dalla-Costa, L. M., Coelho, J. M., Souza, H. A., Castro, M. E., Stier, C. J., Bragagnolo, K. L., et al. (2003). Outbreak of carbapenem-resistant Acinetobacter baumannii producing the OXA-23 enzyme in Curitiba, Brazil. J. Clin. Microbiol. 41, 3403-3406. doi: 10.1128/JCM.41.7.34033406.2003

De, R., Kundu, P., Swarnakar, S., Ramamurthy, T., Chowdhury, A., Nair, G. B., et al. (2009). Antimicrobial activity of curcumin against Helicobacter pylori isolates from India and during infections in mice. Antimicrob. Agents Chemother. 53, 1592-1597. doi: 10.1128/AAC.01242-08

Djeussi, D. E., Noumedem, J. A., Seukep, J. A., Fankam, A. G., Voukeng, I. K., Tankeo, S. B., et al. (2013). Antibacterial activities of selected edible plants extracts against multidrug-resistant Gram-negative bacteria. $B M C$ Complement. Altern. Med. 13:164. doi: 10.1186/1472-6882-13-164

Dunn, W. B., Broadhurst, D. I., Atherton, H. J., Goodacre, R., and Griffin, J. L. (2011). Systems level studies of mammalian metabolomes: the roles of mass spectrometry and nuclear magnetic resonance spectroscopy. Chem. Soc. Rev. 40, 387-426. doi: 10.1039/B906712B

Dunn, W. B., and Ellis, D. I. (2005). Metabolomics: current analytical platforms and methodologies. Trends Anal. Chem. 24, 285-294. doi: 10.1016/j.trac.2004.11.021

Endo, S., Yano, H., Hirakata, Y., Arai, K., Kanamori, H., Ogawa, M., et al. (2012). Molecular epidemiology of carbapenem-non-susceptible Acinetobacter baumannii in Japan. J. Antimicrob. Chemother. 67, 1623-1626. doi: 10.1093/jac/dks094

Ettefagh, K. A., Burns, J. T., Junio, H. A., Kaatz, G. W., and Cech, N. B. (2011). Goldenseal (Hydrastis canadensis L.) extracts synergistically enhance the antibacterial activity of berberine via efflux pump inhibition. Planta Med. 77, 835-840. doi: 10.1055/s-0030-1250606

Fabry, W., Okemo, P. O., and Ansorg, R. (1998). Antibacterial activity of East African medicinal plants. J. Ethnopharmacol. 60, 79-84. doi: 10.1016/S03788741(97)00128-1

Fernandez-Cuenca, F., Martinez-Martinez, L., Conejo, M. C., Ayala, J. A., Perea, E. J., and Pascual, A. (2003). Relationship between beta-lactamase production, outer membrane protein and penicillin-binding protein profiles on the activity of carbapenems against clinical isolates of Acinetobacter baumannii. J. Antimicrob. Chemother. 51, 565-574. doi: 10.1093/jac/dkg097

Formisano, C., Rigano, D., Senatore, F., Raimondo, F. M., Maggio, A., and Bruno, M. (2012). Essential oil composition and antibacterial activity of Anthemis mixta and A. tomentosa (Asteraceae). Nat. Prod. Commun. 7, 1379-1382.
Gales, A. C., Tognim, M. C., Reis, A. O., Jones, R. N., and Sader, H. S. (2003). Emergence of an IMP-like metallo-enzyme in an Acinetobacter baumannii clinical strain from a Brazilian teaching hospital. Diagn. Microbiol. Infect. Dis. 45, 77-79. doi: 10.1016/S0732-8893(02)00500-X

Gill, A. O., and Holley, R. A. (2006). Disruption of Escherichia coli, Listeria monocytogenes and Lactobacillus sakei cellular membranes by plant oil aromatics. Int. J. Food Microbiol. 108, 1-9. doi: 10.1016/j.ijfoodmicro.2005.10.009

Gordon, N. C., and Wareham, D. W. (2010). Antimicrobial activity of the green tea polyphenol (-)-epigallocatechin-3-gallate (EGCG) against clinical isolates of Stenotrophomonas maltophilia. Int. J. Antimicrob. Agents 36, 129-131. doi: 10.1016/j.ijantimicag.2010.03.025

Guclu, E., Genc, H., Zengin, M., and Karabay, O. (2014). Antibacterial activity of Lythrum salicaria against multidrug-resistant Acinetobacter baumannii and Pseudomonas aeruginosa. Annu. Res. Rev. Biol. 4, 1099-1105. doi: 10.9734/ARRB/2014/7357

Hagel, J. M., and Facchini, P. J. (2008). Plant metabolomics: analytical platforms and integration with functional genomics. Phytochem. Rev. 7, 479-497. doi: 10.1007/s11101-007-9086-9

Horrevorts, A., Bergman, K., Kollee, L., Breuker, I., Tjernberg, I., and Dijkshoorn, L. (1995). Clinical and epidemiological investigations of Acinetobacter genomospecies 3 in a neonatal intensive care unit. J. Clin. Microbiol. 33, $1567-1572$.

Hu, P., Huang, P., and Chen, M. W. (2013). Curcumin reduces Streptococcus mutans biofilm formation by inhibiting sortase A activity. Arch. Oral Biol. 58, 1343-1348. doi: 10.1016/j.archoralbio.2013.05.004

Hu, W. S., Yao, S. M., Fung, C. P., Hsieh, Y. P., Liu, C. P., and Lin, J. F. (2007). An OXA-66/OXA-51-like carbapenemase and possibly an efflux pump are associated with resistance to imipenem in Acinetobacter baumannii. Antimicrob. Agents Chemother. 51, 3844-3852. doi: 10.1128/AAC.01512-06

Huang, H. C., Wang, H. F., Yih, K. H., Chang, L. Z., and Chang, T. M. (2012). Dual bioactivities of essential oil extracted from the leaves of Artemisia argyi as an antimelanogenic versus antioxidant agent and chemical composition analysis by GC/MS. Int. J. Mol. Sci. 13, 14679-14697. doi: 10.3390/ijms131114679

Iredell, J., Thomas, L., Power, D., and Mendes, E. (2007). Tigecycline resistance in Australian antibiotic-resistant Gram-negative bacteria. J. Antimicrob. Chemother. 59, 816-818. doi: 10.1093/jac/dkm002

Jacobo-Salcedo Mdel, R., Gonzalez-Espindola, L. A., Alonso-Castro, A. J., Gonzalez-Martinez Mdel, R., Dominguez, F., and Garcia-Carranca, A. (2011). Antimicrobial activity and cytotoxic effects of Magnolia dealbata and its active compounds. Nat. Prod. Commun. 6, 1121-1124.

Jeon, B. C., Jeong, S. H., Bae, I. K., Kwon, S. B., Lee, K., Young, D., et al. (2005). Investigation of a nosocomial outbreak of imipenem-resistant Acinetobacter baumannii producing the OXA-23 beta-lactamase in Korea. J. Clin. Microbiol. 43, 2241-2245. doi: 10.1128/JCM.43.5.2241-2245.2005

Jeong, S. H., Bae, I. K., Park, K. O., An, Y. J., Sohn, S. G., Jang, S. J., et al. (2006). Outbreaks of imipenem-resistant Acinetobacter baumannii producing carbapenemases in Korea. J. Microbiol. 44, 423-431.

Khadri, S., Boutefnouchet, N., and Dekhil, M. (2010). Antibacterial activity evaluation of Allium sativum essential oil compared to different Pseudomonas aeruginosa strains in Eastern algeria. Sci. Stud. Res. Chem. Chem. Eng. Biotechnol. Food Ind. 11, $421-428$.

Kono, K., Tatara, I., Takeda, S., Arakawa, K., Shirotani, T., Okada, M., et al. (1997). Antibacterial activity of epigallocatechin gallate against Helicobacter pylori: synergistic effect with Plaunotol. J. Infect. Chemother. 3, 170-172. doi: 10.1007/BF02491509

Ko, K. S., Suh, J. Y., Kwon, K. T., Jung, S. I., Park, K. H., Kang, C. I., et al. (2007). High rates of resistance to colistin and polymyxin B in subgroups of Acinetobacter baumannii isolates from Korea. J. Antimicrob. Chemother. 60, 1163-1167. doi: 10.1093/jac/dkm305

Koh, T. H., Sng, L. H., Wang, G. C., Hsu, L. Y., and Zhao, Y. (2007). IMP4 and OXA beta-lactamases in Acinetobacter baumannii from Singapore. J. Antimicrob. Chemother. 59, 627-632. doi: 10.1093/jac/dkl544

Kollanoor Johny, A., Darre, M. J., Donoghue, A. M., Donoghue, D. J., and Venkitanarayanan, K. (2010). Antibacterial effect of trans-cinnamaldehyde, eugenol, carvacrol, and thymol on Salmonella enteritidis and Campylobacter 
jejuni in chicken cecal contents in vitro. J. Appl. Poult. Res. 19, 237-244. doi: 10.3382/japr.2010-00181

Lawrence, R., Tripathi, P., and Jeyakumar, E. (2009). Isolation, purification and evaluation of antibacterial agents from aloe vera. Braz. J. Microbiol. 40, 906-915. doi: 10.1590/S1517-83822009000400023

Lewis, K., and Ausubel, F. M. (2006). Prospects for plant-derived antibacterials. Nat. Biotechnol. 24, 1504-1507. doi: 10.1038/nbt1206-1504

Lin, W. R., Lu, P. L., Siu, L. K., Chen, T. C., Lin, C. Y., Hung, C. T., et al. (2011). Rapid control of a hospital-wide outbreak caused by extensively drugresistant OXA-72-producing Acinetobacter baumannii. Kaohsiung J. Med. Sci. 27, 207-214. doi: 10.1016/j.kjms.2010.11.004

Lu, X., Rasco, B. A., Jabal, J. M., Aston, D. E., Lin, M., and Konkel, M. E. (2011). Investigating antibacterial effects of garlic (Allium sativum) concentrate and garlic-derived organosulfur compounds on Campylobacter jejuni by using Fourier transform infrared spectroscopy, Raman spectroscopy, and electron microscopy. Appl. Environ. Microbiol. 77, 5257-5269. doi: 10.1128/AEM.02845-10

Lv, F., and Xu, X. J. (2008). Studies on the chemical constituents of Rabdosia rubescens. Zhong Yao Cai 31, 1340-1343.

Manchanda, V., Sanchaita, S., and Singh, N. (2010). Multidrug resistant acinetobacter. J. Glob. Infect. Dis. 2, 291-304. doi: 10.4103/0974-777X. 68538

Marchaim, D., Navon-Venezia, S., Leavitt, A., Chmelnitsky, I., Schwaber, M. J., and Carmeli, Y. (2007). Molecular and epidemiologic study of polyclonal outbreaks of multidrug-resistant Acinetobacter baumannii infection in an Israeli hospital. Infect. Control Hosp. Epidemiol. 28, 945-950. doi: 10.1086/518970

Masoud, E. A., and Gouda, H. A. (2012). Effect of some natural plant extracts against gram negative bacteria in Njran Area, Saudi Arabia. Egypt. Acad. J. Biolog. Sci. 4, 85-92.

Mendes, R. E., Farrell, D. J., Sader, H. S., and Jones, R. N. (2010). Comprehensive assessment of tigecycline activity tested against a worldwide collection of Acinetobacter spp. (2005-2009). Diagn. Microbiol. Infect. Dis. 68, 307-311. doi: 10.1016/j.diagmicrobio.2010.07.003

Merkier, A. K., and Centron, D. (2006). bla(OXA-51)-type beta-lactamase genes are ubiquitous and vary within a strain in Acinetobacter baumannii. Int. J. Antimicrob. Agents 28, 110-113. doi: 10.1016/j.ijantimicag.2006.03.023

Miyasaki, Y., Rabenstein, J. D., Rhea, J., Crouch, M. L., Mocek, U. M., Kittell, P. E., et al. (2013). Isolation and characterization of antimicrobial compounds in plant extracts against multidrug-resistant Acinetobacter baumannii. PLoS ONE 8:e61594. doi: 10.1371/journal.pone.0061594

Mun, S. H., Joung, D. K., Kim, Y. S., Kang, O. H., Kim, S. B., Seo, Y. S., et al. (2013). Synergistic antibacterial effect of curcumin against methicillin-resistant Staphylococcus aureus. Phytomedicine 20, 714-718. doi: 10.1016/j.phymed.2013.02.006

Nand, P., Drabu, S., and Rk, G. (2012). Insignificant anti-acne activity of Azadirachta indica leaves and bark. J. Pharm. Negat. Results 3, 29-33. doi: 10.4103/0976-9234.99650

Nostro, A., Sudano Roccaro, A., Bisignano, G., Marino, A., Cannatelli, M. A., Pizzimenti, F. C., et al. (2007). Effects of oregano, carvacrol and thymol on Staphylococcus aureus and Staphylococcus epidermidis biofilms. J. Med. Microbiol. 56, 519-523. doi: 10.1099/jmm.0.46804-0

Oleszek, W., and Marston, A. (eds.) (2000). "Saponins in food, feedstuffs and medicinal plants," in Proceedings of the Phytochemical Society of Europe, Vol. 45, 1-95. Available online at: http://www.springer.com/in/book/9780792360230

Osterburg, A., Gardner, J., Hyon, S. H., Neely, A., and Babcock, G. (2009). Highly antibiotic-resistant Acinetobacter baumannii clinical isolates are killed by the green tea polyphenol (-)-epigallocatechin-3-gallate (EGCG). Clin. Microbiol. Infect. 15, 341-346. doi: 10.1111/j.1469-0691.2009.02710.x

Oteo, J., Garcia-Estebanez, C., Miguelanez, S., Campos, J., Marti, S., Vila, J., et al. (2007). Genotypic diversity of imipenem resistant isolates of Acinetobacter baumannii in Spain. J. Infect. 55, 260-266. doi: 10.1016/j.jinf.2007. 04.009

Pacôme, O. A., Bernard, D. N., Sékou, D., Joseph, D. A., David, N. G. J., Mongomaké, K., et al. (2014). Phytochemical and antioxidant activity of Roselle (Hibiscus Sabdariffa L.) petal extracts. Res. J. Pharm. Biol. Chem. Sci. 5, 1453-1465.

Peleg, A. Y., Franklin, C., Bell, J. M., and Spelman, D. W. (2006). Emergence of carbapenem resistance in Acinetobacter baumannii recovered from blood cultures in Australia. Infect. Control Hosp. Epidemiol. 27, 759-761. doi: $10.1086 / 507012$

Pelletier, R. P. (2012). Effect of Plant-Derived Molecules on Acinetobacter baumannii Biofilm on Abiotic Surfaces. Honors Scholar Theses, University of Connecticut, Storrs.

Perez, F., Hujer, A. M., Hujer, K. M., Decker, B. K., Rather, P. N., and Bonomo, R. A. (2007). Global challenge of multidrug-resistant Acinetobacter baumannii. Antimicrob. Agents Chemother. 51, 3471-3484. doi: 10.1128/AAC.01464-06

Phillipson, J. D. (2007). Phytochemistry and pharmacognosy. Phytochemistry 68 , 2960-2972. doi: 10.1016/j.phytochem.2007.06.028

Playford, E. G., Craig, J. C., and Iredell, J. R. (2007). Carbapenem-resistant Acinetobacter baumannii in intensive care unit patients: risk factors for acquisition, infection and their consequences. J. Hosp. Infect. 65, 204-211. doi: 10.1016/j.jhin.2006.11.010

Rai, D., Singh, J. K., Roy, N., and Panda, D. (2008). Curcumin inhibits FtsZ assembly: an attractive mechanism for its antibacterial activity. Biochem. J. 410, 147-155. doi: 10.1042/BJ20070891

Rice, L. B. (2006). Challenges in identifying new antimicrobial agents effective for treating infections with Acinetobacter baumannii and Pseudomonas aeruginosa. Clin. Infect. Dis. 43(Suppl. 2), S100-S105. doi: 10.1086/504487

Riley, T. V., Webb, S. A., Cadwallader, H., Briggs, B. D., Christiansen, L., and Bowman, R. A. (1996). Outbreak of gentamicin-resistant Acinetobacter baumanii in an intensive care unit: clinical, epidemiological and microbiological features. Pathology 28, 359-363. doi: 10.1080/00313029600169354

Rodriguez-Martinez, J. M., Poirel, L., and Nordmann, P. (2010). Genetic and functional variability of AmpC-type beta-lactamases from Acinetobacter baumannii. Antimicrob. Agents Chemother. 54, 4930-4933. doi: 10.1128/AAC.00427-10

Sader, H. S., Castanheira, M., Mendes, R. E., Toleman, M., Walsh, T. R., and Jones, R. N. (2005). Dissemination and diversity of metallo-beta-lactamases in Latin America: report from the SENTRY Antimicrobial Surveillance Program. Int. J. Antimicrob. Agents 25, 57-61. doi: 10.1016/j.ijantimicag.2004. 08.013

Santella, G., Docquier, J. D., Gutkind, G., Rossolini, G. M., and Radice, M. (2011). Purification and biochemical characterization of IMP-13 metallo-beta-lactamase. Antimicrob. Agents Chemother. 55, 399-401. doi: 10.1128/AAC.00421-10

Saulnier, P. M. A. (2014). Aromatic and terpenic compounds loaded in lipidic nanocapsules: activity against multi-drug resistant Acinetobacter baumannii assessed in vitro and in a murine model of sepsis. J. Nanomed. Nanotechnol. 5:206. doi: 10.4172/2157-7439.1000206

Savoia, D. (2012). Plant-derived antimicrobial compounds: alternatives to antibiotics. Future Microbiol. 7, 979-990. doi: 10.2217/fmb.12.68

Shahcheraghi, F., Abbasalipour, M., Feizabadi, M., Ebrahimipour, G., and Akbari, N. (2011). Isolation and genetic characterization of metallo-beta-lactamase and carbapenamase producing strains of Acinetobacter baumannii from patients at Tehran hospitals. Iran. J. Microbiol. 3, 68-74.

Sherertz, R. J., and Sullivan, M. L. (1985). An outbreak of infections with Acinetobacter calcoaceticus in burn patients: contamination of patients' mattresses. J. Infect. Dis. 151, 252-258. doi: 10.1093/infdis/151. 2.252

Stermitz, F. R., Lorenz, P., Tawara, J. N., Zenewicz, L. A., and Lewis, K. (2000). Synergy in a medicinal plant: antimicrobial action of berberine potentiated by 5'-methoxyhydnocarpin, a multidrug pump inhibitor. Proc. Natl. Acad. Sci. U.S.A. 97, 1433-1437. doi: 10.1073/pnas.030540597

Tiwari, V., Kapil, A., and Moganty, R. R. (2012). Carbapenem-hydrolyzing oxacillinase in high resistant strains of Acinetobacter baumannii isolated from India. Microb. Pathog. 53, 81-86. doi: 10.1016/j.micpath.2012. 05.004

Tiwari, V., and Moganty, R. R. (2013). Structural studies on New Delhi Metallobeta-lactamase (NDM-2) suggest old beta-lactam, penicillin to be better antibiotic for NDM-2-harbouring Acinetobacter baumanni. J. Biomol. Struct. Dyn. 31, 591-601. doi: 10.1080/07391102.2012.706075

Tiwari, V., and Moganty, R. R. (2014). Conformational stability of OXA-51 beta-lactamase explains its role in carbapenem resistance of Acinetobacter baumannii. J. Biomol. Struct. Dyn. 32, 1406-1420. doi: 10.1080/07391102.2013.819789 
Tiwari, V., and Tiwari, M. (2014). Quantitative proteomics to study carbapenem resistance in Acinetobacter baumannii. Front. Microbiol. 5:512. doi: $10.3389 /$ fmicb.2014.00512

Tiwari, V., and Tiwari, M. (2015). Phosphoproteomics as an emerging weapon to develop new antibiotics against carbapenem resistant strain of Acinetobacter baumannii. J. Proteomics. 112, 336-338. doi: 10.1016/j.jprot.2014. 09.008

Tognim, M. C., Gales, A. C., Penteado, A. P., Silbert, S., and Sader, H. S. (2006). Dissemination of IMP-1 metallo- beta -lactamase-producing Acinetobacter species in a Brazilian teaching hospital. Infect. Control Hosp. Epidemiol. 27, 742-747. doi: 10.1086/504356

Ultee, A., Bennik, M. H., and Moezelaar, R. (2002). The phenolic hydroxyl group of carvacrol is essential for action against the food-borne pathogen Bacillus cereus. Appl. Environ. Microbiol. 68, 1561-1568. doi: 10.1128/aem.68.4.1561-1568.2002

Valenzuela, J. K., Thomas, L., Partridge, S. R., van der Reijden, T., Dijkshoorn, L., and Iredell, J. (2007). Horizontal gene transfer in a polyclonal outbreak of carbapenem-resistant Acinetobacter baumannii. J. Clin. Microbiol. 45, 453-460. doi: 10.1128/JCM.01971-06

Vashist, J., Tiwari, V., Kapil, A., and Rajeswari, M. R. (2010). Quantitative profiling and identification of outer membrane proteins of beta-lactam resistant strain of Acinetobacter baumannii. J. Proteome Res. 9, 1121-1128. doi: $10.1021 /$ pr9011188

Vila, J., Marti, S., and Sanchez-Cespedes, J. (2007). Porins, efflux pumps and multidrug resistance in Acinetobacter baumannii. J. Antimicrob. Chemother. 59, 1210-1215. doi: 10.1093/jac/dkl509

Villas-Boas, S. G., Mas, S., Akesson, M., Smedsgaard, J., and Nielsen, J. (2005). Mass spectrometry in metabolome analysis. Mass Spectrom. Rev. 24, 613-646. doi: 10.1002/mas.20032

Villegas, M. V., Kattan, J. N., Correa, A., Lolans, K., Guzman, A. M., Woodford, N., et al. (2007). Dissemination of Acinetobacter baumannii clones with OXA23 Carbapenemase in Colombian hospitals. Antimicrob. Agents Chemother. 51, 2001-2004. doi: 10.1128/AAC.00226-07

Wang, Y., Chang, L., Zhao, X., Meng, X., and Liu, Y. (2012). Gas chromatographymass spectrometry analysis on compounds in volatile oils extracted from yuan zhi (Radix polygalae) and shi chang pu (Acorus tatarinowii) by supercritical $\mathrm{CO}_{2}$. J. Tradit. Chin. Med. 32, 459-464. doi: 10.1016/S0254-6272(13)60055-2

Wang, Y. F., and Dowzicky, M. J. (2010). In vitro activity of tigecycline and comparators on Acinetobacter spp. isolates collected from patients with bacteremia and MIC change during the Tigecycline Evaluation and Surveillance Trial, 2004 to 2008. Diagn. Microbiol. Infect. Dis. 68, 73-79. doi: 10.1016/j.diagmicrobio.2010.04.002

Weernink, A., Severin, W. P., Tjernberg, I., and Dijkshoorn, L. (1995). Pillows, an unexpected source of Acinetobacter. J. Hosp. Infect. 29, 189-199. doi: 10.1016/0195-6701(95)90328-3

Wilke, M. S., Lovering, A. L., and Strynadka, N. C. (2005). Beta-lactam antibiotic resistance: a current structural perspective. Curr. Opin. Microbiol. 8, 525-533. doi: 10.1016/j.mib.2005.08.016

Zarrilli, R., Giannouli, M., Tomasone, F., Triassi, M., and Tsakris, A. (2009). Carbapenem resistance in Acinetobacter baumannii: the molecular epidemic features of an emerging problem in health care facilities. J. Infect. Dev. Ctries. 3, 335-341. doi: 10.3855/jidc. 240

Zhao, W. H., Hu, Z. Q., Hara, Y., and Shimamura, T. (2002). Inhibition of penicillinase by epigallocatechin gallate resulting in restoration of antibacterial activity of penicillin against penicillinase-producing Staphylococcus aureus. Antimicrob. Agents Chemother. 46, 2266-2268. doi: 10.1128/AAC.46.7.22662268.2002

Conflict of Interest Statement: The authors declare that the research was conducted in the absence of any commercial or financial relationships that could be construed as a potential conflict of interest.

Copyright (C) 2015 Tiwari, Roy and Tiwari. This is an open-access article distributed under the terms of the Creative Commons Attribution License (CC BY). The use, distribution or reproduction in other forums is permitted, provided the original author(s) or licensor are credited and that the original publication in this journal is cited, in accordance with accepted academic practice. No use, distribution or reproduction is permitted which does not comply with these terms. 